\title{
Pathways to electricity for all: What makes village-scale solar power successful?
}

\author{
Kirsten Ulsrud ${ }^{\mathrm{a},{ }^{*}}$, Harald Rohracher ${ }^{\mathrm{b}}$, Tanja Winther ${ }^{\mathrm{c}}$, Charles Muchunku ${ }^{\mathrm{d}}$, Debajit Palit ${ }^{\mathrm{e}}$ \\ ${ }^{a}$ Department of Sociology and Human Geography, University of Oslo, PO Box 1096, Blindern, N-0317 \\ Oslo, Norway \\ ${ }^{\mathrm{b}}$ Linköping University, Sweden \\ ${ }^{c}$ Centre for Development and the Environment (SUM), University of Oslo, Norway \\ ${ }^{\mathrm{d}}$ Independent Energy Consultant, Kenya \\ e TERI, India
}

Published as: Ulsrud, K., Rohracher, H., Winther, T., Muchunku, C. and Palit, D. (2018): 'Pathways to electricity for all: What makes village-scale solar power successful?', Energy Research \& Social Science 44: 32-40, https://doi.org/10.1016/j.erss.2018.04.027

\begin{abstract}
This article presents new empirical research on what it takes to provide enduring access to affordable, reliable and useful electricity services for all. We analyze and synthesize the long-term experiences with three different systems for village-scale solar power supply in India, Senegal and Kenya. Since this scale of electricity provision forms part of village infrastructure, it requires particular types of knowledge, policies and support mechanisms. This research therefore investigates how village-scale solar systems can be designed, implemented, sustained and replicated in ways that make them accessible and useful for the community members. Drawing on a socio-technical and practice-oriented approach, we show that the electricity system's degree of adaptedness to its social context affects many important qualities of the system such as the relevance of the available electricity services for the people, the system's operational and economic sustainability and the potential for replication. Achieving such adaptation notably requires a flexible approach on the part of implementers, funders and local actors before, during and after implementation. We also show the need for institutionalization of decentralized electricity provision, discuss the current ambiguities in policies, regulations and funding mechanisms for villagescale solar power, and provide recommendations to policy makers and donors.
\end{abstract}




\section{Introduction}

An increasing number of households, businesses and public institutions find opportunities to transit from traditional off-grid solutions such as kerosene lamps, paraffin candles and diesel generators to the use of electricity from solar photovoltaic (PV) systems at different scales, including mini-grids (IRENA 2017). However, solar PV technology is still only benefiting a small portion of those without conventional electricity access (IEA 2014, GOGLA 2015, Bloomberg 2016). Moreover, the growth in the use of solar power has mainly been limited to small systems providing basic services, especially light and phone charging (Bloomberg 2016). How, then, may one realize the untapped potential to utilize solar electricity for a wider range of electric services and for a much larger number of users? In Africa for instance, we have probably seen only the beginning of a process towards increased utilization of the enormous solar resources, both through grid and off-grid solar PV (IRENA 2016). The research presented in this article aims to contribute to new knowledge about this constantly changing field, for the sake of the further progress towards realizing this potential. To this aim, it is crucial to analyze existing long-term experiences with solar power systems in terms of how they may be organized, operated and maintained so as to reach remote areas, become economically sustainable, and provide affordable and reliable electricity services to all in different geographical contexts. As we will show, some of these goals (e.g. affordability and economic sustainability are sometimes conflicting, inviting attention to how different goals are balanced and managed in practice.)

Focusing on the scale of electricity provision is also necessary because it strongly influences the ways in which these systems are financed, organized, sustained and scaled up, as well as the opportunities and responsibilities they imply for users (Bridge et al. 2013, Ulsrud et al. 2011, Ulsrud et al. 2015). There are three main scales for use of solar PV technology. The first scale is standalone solar PV systems for individual users. Social science studies of such systems have focused on business models, operational and economic aspects, affordability and socio-economic impacts (Bellanca et al. 2013, Camblong et al. 2009, Chaurey et al. 2004, Jakobson 2007, Jolly et al. 2002); The second is the village or community scale; as described in the following, and the third is larger scale, often grid connected use of solar PV. In the present discussion, we have chosen to study electricity supply organized at the village scale, which includes mini-grids, energy charging centers and other small-scale solar energy models of villages. Since such solar power supply forms part of village infrastructure, its successful implementation requires other types of knowledge, policies and support mechanisms than individual standalone systems and centralized grid electricity supply as shown by previous studies (Bhattacharya and Palit 2014, Chaurey and Kandpal 2010, Millinger et al. 2012, Palit 2013, Shrank 2008, Wong 2012).

When choosing to study this particular type of delivery model for solar power, we do not dismiss the potential importance of other kinds of systems, but village scale systems are interesting for several reasons. Firstly, they have a potential to increase the number of people with access to electricity in each 
community and increase the range of electricity services available. Secondly, they free users from the responsibility to invest in equipment, operation as well as battery replacement and other large and small maintenance. Thirdly, they provide good opportunities for the use of more power-demanding equipment (IRENA 2016). Not least for these reasons, international energy experts expect village scale systems to play an important role to achieve universal access (IEA 2011, IRENA 2016). Small, solar PV based mini-grids can serve small remote settlements that would usually not be considered for electrification through grids or large conventional mini-grids because they lack the economies of scale (potential number and size of customers) to make conventional electrification technically or economically viable and because these settlements are usually in areas with very limited economic activity. Also, in East Africa it has been observed that private solar businesses are reluctant towards establishing sales and service infrastructure in remote areas because it is difficult to become profitable (Muchunku et al. 2018).

We currently see the emergence of large mini-grid initiatives, several of them in Africa, with solar PV as the most important technology (Carlin et al. 2017). These initiatives make this kind of research particularly relevant, because parts of the massive funding now going into mini-grids, in Senegal for instance, do not put sufficient efforts on obtaining sustainability according to donors, project implementers and energy experts in Senegal and India observing these trends (personal communication, Ulsrud et al. forthcoming). Some of the programs follow organizational models that have previously led to breakdowns. There is thus an urgent need to learn from the long-term experiences of various types of village-scale systems in different geographical, socio-cultural and political contexts.

In order to contribute to the knowledge needed for the success of village-scale solar power supply, we have conducted three detailed case studies, one in Senegal in West Africa, one in Kenya in East Africa, and one in India (Chhattisgarh state). These examples have been operating over several years, while also being innovative and expanding beyond the initial area for implementation. Our aim is to increase the understanding of factors that influence the achievements of such decentralized electricity supply models, considering the following criteria:

- Well-functioning system (in terms of long-term operational and economic sustainability)

- Good quality electricity access that fits with people's needs and economic situation (affordable, accessible, reliable, useful)

- The possibility to replicate the electricity supply model in large numbers

Based on previous studies (e.g. Ahlborg \& Sjöstedt 2015. Ulsrud et al. 2011, Ulsrud et al. 2015), we assume that the factors that influence the achievements can be found within the following broad dimensions: 
- The social and technological (socio-technical) design or configuration of the electricity system including ownership, types of services and distribution, and the way in which it is planned and implemented

- The degree of adaptedness to the social and cultural context at the local level, including socioeconomic conditions, settlement patterns and the different needs of various groups

- Political factors and other national and international framework conditions

We will study the selected systems with respect to these factors. In the following, we proceed in Section 2 by accounting for the analytic framework and previous studies that have addressed components of the framework. Then we account for the methods (Section 3) and present the empirical findings, (Sections 4 to 6) following the structure of our analytical framework. Section 7 discusses the findings. In Section 8 we conclude and point out some key choices policy makers and donors will have to make if they aim to include sustainable, village-scale power supply in the future energy mix.

\section{A framework for analyzing village-scale solar power plants}

In this section we present a conceptual framework suitable for analyzing the variation of village-scale solar power supply systems. We build our framework on science, technology and innovation studies, by not merely focusing on technological dimensions or economic viability, but also by analyzing the solar power provision as socio-technical systems where the technological components cannot be separated from organizational, social, cultural and political dimensions of the systems (Williams and Sørensen 2001, Russell and Williams 2002, Geels 2011). We also view the village-scale supply systems as part of larger processes of system innovation, institutionalization and emerging transitions to low-carbon energy systems (Berkhout et al. 2010). These processes influence the institutional and regulatory frameworks that in turn influence how village-scale systems are designed, implemented, sustained and replicated in different geographical areas.

In addition to these socio-technical system approaches, we also build on literature on energy access as well as practice theory because a given system always interacts with end users. Social practice theory provides important insights on this interrelationship due to the repetitive character of energy provision and use and the way material and socio-cultural structures such as local knowledge, ideas of progress, norms and values shape what people do with energy (Shove 2003, Wilhite 2008a and 2008b, Winther 2008). Energy practices may in turn influence the operational and economic sustainability of the electricity provision and the qualities of the electricity services (Ulsrud et al. 2011).

Through the analytical framework we aim to get a better understanding of three dimensions of our empirical cases of village-scale solar power supply. Firstly, these systems can be characterized as specific socio-technical configurations. Here we address the socio-technical design and organizational model of the energy supply systems, as well as the geographical, cultural and institutional contexts these 
systems are embedded in at the local and national level. Secondly, we analyze the evolving social practices of operating, maintaining and using the solar power plants and the impacts they have on energy access. Thirdly, we reflect on the conditions for further replicating or up-scaling the particular models we found in our case analyses. In the following, we spell out more details of our analytical approach.

\subsection{Socio-technical configurations of energy supply}

Any village-scale power plant has a particular socio-technical design. By design we not only refer to the technical design parameters and components involved, but also the energy services provided and the organizational and economic features of the supply system. Such features include the system's financing model, the setting of tariffs and collection of electricity fees, the types and responsibilities of actors involved in operation and maintenance, as well as the rules for regulating subscriptions, consumption, metering, payment and compliance.

Electricity supply systems become embedded in a particular local, social and cultural context which need to be taken into account in the design phase. The type and degree of social embeddedness can either create frictions with the way the plant is operated and used, or become an important factor for the success of the electricity supply system. Population density, settlement patterns and socio-economic conditions form part of these local contexts and condition electricity use in important ways (Chaurey and Kandpal 2010). The level of economic activity in the village may influence how the system is designed and how it works in practice (Kirubi et al. 2009). Affluence tends to be unequally distributed, and because electricity has to be paid for, poorer groups risk being excluded from access (Winther 2008, Leach et al. 2010, Winther et al. forthcoming/this volume). It is therefore important to understand the daily struggles of various groups and the hindrances they face for taking advantage of the available electricity services. By focusing on the relationship between 'the delivery model' of electricity supply and the context in which it becomes introduced, lessons can be drawn on factors that influence how the system works in practice, and the kind of electricity access it gives and for whom (Ockwell and Byrne 2017, Ulsrud et al. 2011, Rolffs et al. 2015, Winther 2008, Ulsrud 2015, Standal et al. forthcoming, Ahlborg 2017, Rohracher 2003).

Beyond these local conditions and contexts, policies and other national and international framework conditions may be important enablers or limitations to the socio-technical design of the plant. Examples of such contextual factors are political ideologies on the role of the state and market, regulations and various institutions (Bhattacharyya and Palit 2016, Newell and Phillips 2016, Ockwell and Byrne 2017). Other examples are subsidies, economic interests and lack of political priority (IEA 2011, Yadoo and Cruickshank 2012). Such aspects of the political economy can exist on different geographical scales or levels of governance and work across spatial contexts (Bridge et al. 2013, Ockwell et al. 2017). Broader 
societal trends not related to electricity supply are also likely to play a role, including historical developments in a region or country.

\subsection{Practices of operation and use}

The way the local electricity system performs in practice and its long-term sustainability may deviate in important ways from the socio-technical design of the system. The actual functioning of socio-technical configurations always differs from what has been planned and anticipated (Russell and Williams 2002). The system's functioning depends on the interaction between technical and social elements of the system, the interaction between the involved actors, as well as interaction and embedding between the system and the contextual dimensions. Operational and economic sustainability are central aspects. Operational sustainability is the system's ability to have continuous operation and maintenance, while economic sustainability is the system's ability to cover the costs of operation and maintenance and create a surplus for expansion. Learning processes after implementation are unpredictable, iterative processes of reconfiguring technical and social elements of the system design. For instance, the users of technologies may develop their own practices of use which in turn may also lead to adaptations of technical components or organizational structures (Ornetzeder and Rohracher 2005, Williams and Sørensen 2002).

The socio-technical design and emerging practices of operation and use also shape the types of electricity access created: Who gets access (including the gender), in which places and for which reasons? Moreover, the perceptions of the users and non-users of the system are relevant. It is also important to understand why some people take upon them the efforts and costs for switching from previous uses of energy, and what is hindering others from doing the same.

\subsection{Up-scaling and replication}

In the last step of our analysis we go beyond the specific, local cases and ask for the potential of replication and up-scaling of delivery models tested in the pilot projects. Replication is here taken to mean that project implementers or others build on a model they have tried out or observed, and repeat or further develop elements of it in new activities, in larger numbers of units. Replication is rarely or never a direct copy of a socio-technical configuration, because lessons are learned and additional ideas are brought in underway (Brown and Vergragt 2008). With up-scaling we mean moving from smallscale projects, e.g. supplying a fraction of a village, to larger-size energy supply systems at different geographical scales (see also Naber et al., 2017, on different dimensions of up-scaling). Replication and up-scaling requires institutionalization in terms of gradually re-directing institutional, economic, and political commitments (Smith and Stirling 2010). The actors who are drivers of socio-technical innovation often initiate such "institutional work" (Fuenfschilling and Truffer 2014). 


\section{Research methods}

The empirical case studies of village-level solar power systems in India, Kenya and Senegal were each chosen because of features that make them particularly relevant for future activities on village scale solar systems. The Indian case, for instance, represents an example of large up-scaling and institutionalization of village scale solar power supply by the public sector, including an innovative arrangement for follow-up and maintenance, which may provide lessons for private sector actors as well. One of the salient aspects of the Kenyan case is that it was initially meant to be a solar mini-grid project, while the planning process showed that a mini-grid model would not be feasible due to various contextual factors. The case is also interesting because the Government of Kenya is implementing solar lantern charging stations based on ideas from this pilot project. The Senegalese case, which has not been investigated by social science based researchers before, is an example of a private sector led mini-grid project with ambitions to create a profitable business model, where regulatory barriers became key issues. The lead company continues to start new mini-grids in other African countries based on the lessons learned in Senegal, trying to solve both regulatory, technical and economic hindrances and shortcomings.

The case studies were carried out jointly by social scientists and technical experts, the Indian case study in 2015 and the Senegalese in 2016. The Kenyan case study was an action research project lasting from 2009 until 2017, and was carried out by the authors of this article and other participants from India, Kenya and Norway, led by the University of Oslo, Norway. Data was collected continuously and the analysis was carried out with consciousness about issues of positionality associated with being insiders of the project (Herr and Anderson 2005, Kalleberg 2009). For an elaborate description of the action research and its impacts on the research results, see Ulsrud (2015).

The research is mainly based on qualitative interviews, observation and participation, because detailed case studies with emphasis on qualitative methods have the potential to provide deep understanding of what is going on in the studied unit and why. The informants have been selected to show the perspectives of the variety of actors that have an impact on, observe or are impacted by the analyzed socio-technical changes.

The comparison of the cases is of a qualitative kind, as described by Patton (2002). The three case studies were conducted separately with the aim to understand each case as a whole, before contrasting the findings in order to provide additional perspectives. 
Table 1: Data collected in the three case studies

\begin{tabular}{|c|c|c|c|}
\hline Type of data & India & Kenya & Senegal \\
\hline $\begin{array}{l}\text { Qualitative interviews with } \\
\text { users and non-users } \\
\text { (households, businesses) }\end{array}$ & $\begin{array}{l}5 \text { group interviews, } 6 \\
\text { individual interviews }\end{array}$ & $\begin{array}{l}47 \text { semi-structured } \\
\text { interviews, a large number } \\
\text { of informal conversations, } \\
\text { and four public meetings }\end{array}$ & $\begin{array}{l}36 \text { households and } 2 \\
\text { groups }\end{array}$ \\
\hline $\begin{array}{l}\text { Quantitative household } \\
\text { surveys }\end{array}$ & 70 households & $\begin{array}{l}\text { Three surveys (with } 70 \text {, } \\
1100 \text { and } 18 \text { respondents). } \\
\text { Mapping with GPS of all } \\
\text { households in Ikisaya } \\
\text { village. Analysis of power } \\
\text { plant statistics over } 3 \text { years } \\
\text { (monthly revenue, expenses, } \\
\text { services used). }\end{array}$ & 52 households \\
\hline $\begin{array}{l}\text { Qualitative interviews, } \\
\text { meetings, and informal } \\
\text { conversations with } \\
\text { different actors involved in } \\
\text { or influencing the } \\
\text { electricity supply }\end{array}$ & $\begin{array}{l}6 \text { state government } \\
\text { officials, } 1 \text { private } \\
\text { sector company, } 13 \\
\text { operators, technicians, } \\
\text { district and region } \\
\text { engineers, } 8 \text { officers at } \\
\text { state, zone and } \\
\text { regional level }\end{array}$ & $\begin{array}{l}\text { More than } 80 \text { (including } \\
\text { conversations with members } \\
\text { of the project team) }\end{array}$ & $\begin{array}{l}40 \text { hours with the project } \\
\text { implementer, } 12 \text { hours } \\
\text { with other key people }\end{array}$ \\
\hline $\begin{array}{l}\text { Qualitative interviews with } \\
\text { actors at the national and } \\
\text { international level } \\
\text { (Government officials, } \\
\text { donors, companies, NGOs) }\end{array}$ & $\begin{array}{l}2 \text {, in addition to } 7 \\
\text { done in } 2010 \text { in } \\
\text { relation to another } \\
\text { mini-grid case in India }\end{array}$ & $\begin{array}{l}43 \text { meetings/interviews, } \\
\text { workshop in } 2012 \text { with } 56 \\
\text { participants }\end{array}$ & 10 informants \\
\hline Observation & $\begin{array}{l}\text { Observation of the } \\
\text { conditions of the } \\
\text { technical equipment, } \\
\text { illegal installations in } \\
\text { customer's buildings, } \\
\text { and supply in the } \\
\text { evening }\end{array}$ & $\begin{array}{l}\text { Long-term participant } \\
\text { observation from } 2009 \text { - } \\
2016 \text {, more than } 25 \text { visits by } \\
\text { different researchers, } 1-2 \\
\text { weeks long }\end{array}$ & \\
\hline Documents & $\begin{array}{l}\text { Technical } \\
\text { descriptions, policy } \\
\text { documents, program } \\
\text { descriptions }\end{array}$ & $\begin{array}{l}\text { Financial reports, bank } \\
\text { statements ( } 3 \text { years), } \\
\text { minutes from staff and } \\
\text { board meetings }\end{array}$ & $\begin{array}{l}\text { Technical descriptions, } \\
\text { survey for demand } \\
\text { assessment, planning } \\
\text { documents }\end{array}$ \\
\hline
\end{tabular}

\section{Three systems for village scale solar power supply: Socio-technical designs and the role of contextual factors for the designs}

In the following we present the particular socio-technical design and implementation of the electricity delivery models and how they, in their early phases, were influenced by their respective policy and regulatory frameworks and social contexts in the rural places.

The three models were all based on small solar PV power plants, each placed in a central part of the villages. In the Indian case, the solar panels were placed on the ground or on top of the power plant buildings. Due to the dense settlements in these villages, gridlines could be stretched to most houses, reaching the majority of the population. Households in the outskirts were provided with solar home systems. In the Kenyan villages, the solar panels were placed on the roof of the power plant buildings. 
Instead of gridlines distributing the electricity, the users came to the power plant to get electricity services, including renting of portable electric lanterns charged at the power plant. This was due to highly dispersed settlement structures and likens a mini-grid model where the gridlines have been eliminated. In the Senegalese villages, with much higher density in settlements, the majority of the residents were connected to the solar mini-grids. These were technically rather advanced and represented a new generation of solar mini-grids compared with the Indian, which were mostly implemented more than a decade back. For an overview of power plant sizes, services delivered, ownership and operation, see table 2 below.

Table 2: The socio-technical designs of the three village-scale solar power plants

\begin{tabular}{|c|c|c|c|}
\hline & Chhattisgarh, India & Kitui, Kenya & Thies, Senegal \\
\hline Owned by & $\begin{array}{l}\text { Chhattisgarh RE } \\
\text { Development Agency } \\
\text { (State Government entity) }\end{array}$ & Solar Transitions Project & Private company \\
\hline $\begin{array}{l}\text { Type of } \\
\text { system }\end{array}$ & Small solar PV mini-grid & $\begin{array}{l}\text { Solar PV energy center and } \\
\text { energy agent }\end{array}$ & $\begin{array}{l}\text { Small solar PV mini- } \\
\text { grid with back-up } \\
\text { diesel generator }\end{array}$ \\
\hline Size & $1-8 \mathrm{kWp}$ & $\begin{array}{l}\text { Energy center: } 2.16 \mathrm{~kW} \\
\text { energy agent: } 80-100 \mathrm{~W}\end{array}$ & $10-15 \mathrm{kWp}$ \\
\hline $\begin{array}{l}\text { Cost of } \\
\text { plant }\end{array}$ & $7,500-10,700 \$$ & $\begin{array}{l}\text { Energy center: } 50,000 \$ \\
\text { Energy agent: } 2,300 \$ \text { per } \\
\text { agent system }\end{array}$ & $91,000 \$$ \\
\hline $\begin{array}{l}\text { Services } \\
\text { provided }\end{array}$ & $\begin{array}{l}2 \text { lighting points per } \\
\text { household (11Wp compact } \\
\text { fluorescent) and street } \\
\text { lighting. Currently, LED } \\
\text { bulbs are provided and CFL } \\
\text { lamps are being replaced. } \\
\text { A socket was included in } \\
\text { newer mini-grids }\end{array}$ & $\begin{array}{l}\text { Energy center: Lantern } \\
\text { renting, phone charging, } \\
\text { sale of lighting products, } \\
\text { barber services, printing, } \\
\text { photocopying, computer } \\
\text { services, TV and video } \\
\text { shows and a meeting room } \\
\text { Energy agent: Lantern } \\
\text { renting, phone charging }\end{array}$ & $\begin{array}{l}\text { Can serve electric } \\
\text { loads of up to } 2 \mathrm{~kW} \\
\text { (most commonly used } \\
\text { range from } 50-200 \mathrm{~W} \text { ) }\end{array}$ \\
\hline $\begin{array}{l}\text { Timing and } \\
\text { flexibility of } \\
\text { services }\end{array}$ & $\begin{array}{l}\text { System designed to provide } \\
\text { electricity for } 5-6 \text { hours a } \\
\text { day }\end{array}$ & $\begin{array}{l}\text { Centre and agents operate } \\
\text { from } 8 \mathrm{am}-8 \mathrm{pm} \text { and } \\
\text { services are provided on } \\
\text { demand }\end{array}$ & $\begin{array}{l}\text { System designed to } \\
\text { provide electricity for } \\
24 \text { hours a day }\end{array}$ \\
\hline $\begin{array}{l}\text { Operated } \\
\text { and } \\
\text { maintained } \\
\text { by }\end{array}$ & $\begin{array}{l}\text { Usually outsourced to a } \\
\text { service provider (private } \\
\text { entity). O\&M team } \\
\text { comprises village operators, } \\
\text { cluster technicians and } \\
\text { supervisors, the two latter } \\
\text { from the service provider. } \\
\text { CREDA has also directly } \\
\text { taken care of maintenance }\end{array}$ & $\begin{array}{l}\text { Community based } \\
\text { organization who employ } \\
\text { full time staff to run the } \\
\text { energy centre and manage } \\
\text { the energy agents }\end{array}$ & $\begin{array}{l}\text { Private company that } \\
\text { owns the micro-grid. } \\
\text { Employs one person in } \\
\text { each village to handle } \\
\text { payment and report to } \\
\text { the company. }\end{array}$ \\
\hline $\begin{array}{l}\text { Payment } \\
\text { mode }\end{array}$ & $\begin{array}{l}\text { Fixed monthly fee } \\
\text { (irrespective of usage } \\
\text { (usage not metered)) }\end{array}$ & $\begin{array}{l}\text { Fees charged for services } \\
\text { used. Customers only pay } \\
\text { when they use a service }\end{array}$ & $\begin{array}{l}\text { Prepaid fee based on } \\
\text { defined energy } \\
\text { block/bundle }\end{array}$ \\
\hline
\end{tabular}




\begin{tabular}{|c|c|c|c|}
\hline $\begin{array}{l}\text { Number of } \\
\text { power } \\
\text { plants }\end{array}$ & 1,702 by October 2016 & $\begin{array}{l}1 \text { energy centre and } 10 \\
\text { energy agents }\end{array}$ & 6 \\
\hline $\begin{array}{l}\text { Economic } \\
\text { design }\end{array}$ & $\begin{array}{l}\text { Financed by the national } \\
\text { government (through the } \\
\text { Ministry of New and } \\
\text { Renewable Energy (MNRE) } \\
\text { and the Ministry of Power } \\
\text { (MoP) and the Chhattisgarh } \\
\text { State Government. Intended } \\
\text { to cover some of the costs for } \\
\text { operation and maintenance. } \\
\text { The rest to be covered by the } \\
\text { state. }\end{array}$ & $\begin{array}{l}\text { Grant financed, intended to } \\
\text { be economically sustainable } \\
\text { in operation and } \\
\text { maintenance. }\end{array}$ & $\begin{array}{l}\text { Private investment is } \\
\text { put in the movable } \\
\text { asset (the power } \\
\text { station) and public } \\
\text { funds (or donor } \\
\text { contributions) used for } \\
\text { the fixed asset (the } \\
\text { distribution network). } \\
\text { Intended to be } \\
\text { commercially } \\
\text { profitable. }\end{array}$ \\
\hline $\begin{array}{l}\text { Tariff } \\
\text { level }\end{array}$ & $\begin{array}{l}0.09 \$ / \text { month (INR 5) } \\
\text { (additionally } 0.4 \$ / \mathrm{kWh} \\
\text { (INR25) is subsidized by the } \\
\text { state government) }\end{array}$ & $\begin{array}{l}\text { Lantern rental }-0.095 \$ / \text { day } \\
\text { Phone charging - } \\
0.19 \$ / \text { charge }\end{array}$ & $1.2 \$ / \mathrm{kWh}$ \\
\hline $\begin{array}{l}\text { Years of } \\
\text { operation }\end{array}$ & 13 years + & 5 years & $\begin{array}{l}3 \text { years for five units, } 7 \\
\text { years for the pilot. }\end{array}$ \\
\hline $\begin{array}{l}\text { Number of } \\
\text { users }\end{array}$ & $\begin{array}{l}\text { An average of } 40-60 \\
\text { connections per micro-grid }\end{array}$ & $\begin{array}{l}130-160 \text { households and } \\
\text { small businesses using the } \\
\text { lantern rental services, } 80- \\
180 \text { using phone charging } \\
\text { services A larger number of } \\
\text { people use photocopying } \\
\text { and typing services } \\
\text { sporadically }\end{array}$ & $\begin{array}{l}50-70 \text { households per } \\
\text { micro-grid }\end{array}$ \\
\hline
\end{tabular}

To a large extent, all the studied systems of supply had been initiated and driven by a company, group or organization who acted as a system builder and whom we refer to as project 'implementers'. They were the ones who created the projects and decided whom else to involve. Even though other actors at the local or national levels were also important, the plants' design and long-term performance very much depended on the implementers' visions for supply, their ideas and knowledge about how it could be put to work and how they took contextual conditions and needs into account. Moreover, the implementers played a key role in ensuring access to resources such as financing.

The driver of the Indian project was Chhattisgarh Renewable Energy Development Agency (CREDA) led by a handful of committed engineers. This state level agency works under the aegis of the federal Ministry of New and Renewable Energy (MNRE). The main vision was to provide affordable light to the high share of Chhattisgarh's population who were living in places that could not be reached by the centralized grid due to their location in hilly and forested, partly protected areas.

The driver of the Kenyan project was an international project team, which included the authors of this paper. The team was composed of social scientists and technology experts and deliberately selected a village that would be typical for rural Kenya and large parts of Sub-Saharan Africa, with a highly 
dispersed settlement pattern and very low income-level. Initially, a mini-grid system was considered, but was not regarded as a viable option (e.g. operation and maintenance cost would not be covered by customer's payment, and grids would reach only a small portion of the households). Hence, the project team's vision became to develop some other kind of power supply that would be suitable in this kind of context.

The Senegalese cluster of projects was created by a company established by German university students in engineering who were motivated to contribute to providing electricity access in Africa. They had developed a new type of electricity meter for mini-grid systems in remote villages and built a business model around this technical device. A business approach was regarded crucial, as the initiators had previously observed many failed projects implemented through development aid.

In addition to the guiding visions mentioned above, all three implementers aimed for operational sustainability, while they had somewhat different ambitions for economic performance. The Indian project had the goal to only cover some of the costs for operation and maintenance through electricity fees, while the Kenyan and Senegalese projects intended to create models that would be economically self-sustained and even give a surplus for modest profit and expansion. However, they all tried to balance considerations for local needs and opportunities with considerations for the sustainability of the systems and they shared the goal of making electricity access affordable to a materially deprived population.

Moreover, contextual factors came into play in two crucial ways. First, the policy framework and the availability of funding largely shaped the project implementers' opportunities and constraints. In India, there were federal policies supporting mini-grid development through institutions such as MNRE and renewable energy agencies, including CREDA, e.g. through the Remote Village Electrification Programme. In addition, the Chhattisgarh state government provides funds covering up to $55 \%$ of the investment costs. These policy interventions and institutionalized promotion and handling of emerging technological alternatives (niche technologies) was important to CREDA's mini-grid initiatives.

The Kenyan project was mainly funded through a Norwegian research grant and was developed independently of the Government of Kenya, although in dialogue with them. The chosen energy model was supposed to be interesting for both private sector companies and the government, due to the determination in the Kenyan energy sector to operate according to business principles. The Kenyan government had no program for supporting solar power supply for households but installed solar PV systems at schools and health clinics and provided tax exemptions on imports of solar PV panels. Kenya also had a private sector driven, donor supported market for solar home systems (Ockwell and Byrne 2017).

The Senegalese project received support by GIZ, a German development cooperation agency, for the power plant buildings and grids (the fixed assets), while the company itself raised funding for the power 
generation equipment, implementation, operation and maintenance. With this division of costs, the model was intended to become an example of public-private-partnerships. The tariff level was set in order to cover the company's costs. The policy framework for private sector mini-grids in Senegal was promising but unfinished when the project was initiated, and the company immediately applied for the license required for supplying electricity through a grid.

Second, the local social context in the three geographical areas conditioned the systems. Despite different geographies and cultures, there are several similarities across the case study areas. People lack jobs and income, and despite the difficult conditions for agriculture, most people depend on this for a livelihood. The education level among adults is relatively low, especially among women. Further characteristics of these contexts are mentioned below in relation to how the solar power supply worked in practice.

The implementers sought to adapt the power systems to the particularities of the social contexts. The leader of the Indian project explained how he walked around in the remote villages in order to understand people's way of living and anticipate what people there might use electricity for. He concluded that light in the evening would be the most relevant service. The Kenyan project team used social science methods to conduct preliminary research on the local context, mapping the situation and needs of various groups while engaging in long-term cooperation with the community. This resulted in electricity services like renting of portable lanterns, typing, photocopying, printing, TV, phone charging and sale of solar lighting equipment at an energy center. The German person who led the practical planning of the Senegalese project lived in Senegal for several years while starting a joint venture with a Senegalese company, and learned about the villages by spending several months there. The company designed their delivery model to accommodate a range of electricity services, from basic services to relatively high power demanding machines (about $2 \mathrm{~kW}$ ). ${ }^{1}$ Part of the planning process in all the three projects was also an assessment of the expected number of users and their ability to pay for services.

\section{Meeting realities: How and why the systems worked as they did in practice}

What happened when the hopeful visions and socio-technical designs met social realities including the contextual factors that had been taken into account during the design phase? In the following we give an account of how the systems for solar power supply worked in practice and why, with a focus on operational and economic sustainability, as well as the quality of electricity access provided.

\subsection{The operational and economic functioning of the local electricity supply systems}

All the cases established relatively robust routines for operation and maintenance, but also faced some challenges. In India, skilled "cluster technicians" hired by private companies on contract with CREDA traveled around on motorbikes and assisted the local operators in the villages. An adaptation to the local

\footnotetext{
${ }^{1}$ For a classification of different levels of electricity access, see the Multi-Tier Framework (ESMAP 2015).
} 
geography and climate was that during the monsoon season, when heavy rain can make roads inaccessible, spare inverters for each cluster were stored locally. If failures occurred, inverters could easily be replaced, reducing the dependency on the manufacturer's technician to come and repair it (Palit et al. 2013). The Indian mini-grids functioned well in some places, while in others they gave very short and unreliable supply. The degree of reliability partly depended on the commitment of individuals and administrative units involved. Social conflicts led to dismantling of a few systems, but Village Energy Committees worked actively to solve such conflicts.

The operation and maintenance of the Kenyan energy center faced relatively few challenges, partly because of gradual operational adjustments based on the lessons learned underway and regular communication between the local actors and the project team. An important change, both to meet demand from surrounding villages and utilize the capacity better was to implement solar lantern renting agents in ten additional villages. The services have been operating continuously since implementation in 2012, while the need to replace batteries have led to temporal reductions in the quality of the services.

Also in the Senegalese case, operation and maintenance was mostly running smoothly, and the supply was mostly reliable. Individual customers sometimes experienced power cuts (subject to automatic disconnection) either because they had exceeded the prescribed load (Watt) or the agreed amount of energy consumption per week. One reason for the operational sustainability was that company staff followed up the power supply and tried to solve problems people encountered, and that operators in the villages acted as contact persons for the customers. However, also advanced and robust equipment was important for the good performance, including the automatic disconnection to avoid degradation of batteries, and a back-up diesel generator.

Economic sustainability was a more difficult target. It is common to expect village-scale electricity systems to be able to sustain themselves economically and give a surplus for expansion (Bellanca et al. 2013, Bhattacharyya and Palit 2014, EUEI PDF 2014, IRENA 2016, ), but this was not realized in the three cases. Earlier studies confirm that economic self-sustainability has been difficult for mini-grids, whether based on solar, micro-hydro or diesel generated power (Kirubi 2009, Ahlborg and Sjöstedt 2015, Ulsrud et al. 2011). The main reason is people's low ability to pay in the areas served by these systems.

In the Indian case, economic performance was not a key criterion for success because the revenue was not expected to cover all costs. Subsidized electricity supply is also an integrated part of the political economy in India (Bhattacharyya 2010, Sareen 2017), and for CREDA a reliable flow of funds for the subsidies was created through a tax on fossil fuels at the state level in Chhattisgarh, which is a coal producing state. However, despite the low tariff, in some areas customers started to reduce their payment and eventually stopped paying for electricity. Limited efforts were made to enforce payment because 
the transaction cost of doing this would have exceeded the increased revenue, and because the tariff was designed to cover only $1 / 6$ of the cost.

In the Kenyan case, the economic performance was also weaker than anticipated. The revenue has covered the costs for operation and maintenance during the five years in operation, but the system's long-term economic sustainability is uncertain. The project team learned that the model can potentially be made economically sustainable by reducing the scope of services to those with the highest demand, i.e. lantern renting and phone charging and thereby using smaller batteries and fewer staff. The main reasons for economic shortcomings were a lower-than-expected frequency in people's use of the services and higher operation costs. Lower use was partly due to the deep poverty level and highly fluctuating incomes depending on seasons and the frequency of droughts. In a survey with 1100 respondents in 11 villages in October 2015 we found that $53 \%$ of the population reported to spend less than $0.08 \$$ for lighting per day and $22 \%$ spent $0.06-0.08 \$$ per day, indicating that daily lantern renting $(0.1 \$$ per day) was not affordable to the majority of the population.

The Senegalese case further illustrates the challenges of achieving good economic performance in these kinds of communities where the socio-economic conditions are very much constrained. The demand for electricity became lower than expected, one reason being that most people were not in a position to create profitable economic activities by the use of electricity. The costs of operation also became higher than expected, with one of the largest expenses related to village visits to follow-up operations and maintenance.

\subsection{The quality of electricity access}

In all the three cases, the implementation of village-scale power provision represented a major and positive shift in opportunities for a significant part of the population by getting access to basic electricity services for the very first time. The presence of the power supply also generated knowledge about electricity and its potential applications. In the Indian case, due to the very low or zero tariff, the demand for electricity in the villages gradually exceeded the capacity of the power plants. After getting access to electrical lighting and mobile phones, many people subsequently developed demand for watching television. This drive was augmented by other socio-cultural changes, such as valuing children's education more. Expansion of mini-grid capacities could not keep up with this rising demand and resulted in reduced hours of supply and more frequent power outages ${ }^{2}$. CREDA responded to the changes, but it took time to finance and implement capacity enhancement in hundreds of villages. Their lack of flexibility was mainly due to budgetary constraints and the particular set-up of the government subsidy provisions in India which required tedious bureaucratic procedures to get funds from the central government.

\footnotetext{
${ }^{2}$ For a similar dynamics observed in the Sunderbans, India, see Ulsrud et al. (2011).
} 
In the Kenyan case, the portion of households and businesses using the lantern services ranged from about $6 \%$ to $30 \%$ in the 11 villages, with the lowest portions in places where the services had recently been introduced. Within a radius of 2-4 km, a larger portion of the population used the lanterns, but accurate figures are not available. The number of users was high compared to the number with access through individual solar home systems when the project started, and included schools, health workers and public offices. Several customers who rented lanterns earlier purchased an individual solar lantern or solar home system, while new people started renting. Solar equipment gradually became cheaper and more easily available in Kenya and is now offered through pay-as-you-go services. However, such solutions cost two to five times as much per day as this lantern renting. Many customers varied the use of lanterns, taking short or long breaks when they could not afford it. People in this area commonly lack money even for food, and some social groups, like single mothers, are in an extremely vulnerable situation. The IT and TV services offered in the pilot village were regarded important by households, businesses, teachers and village leaders, and were also used by people in neighbouring villages. These services were actually subsidized by lantern and phone charging. The portable lanterns were appreciated and suited people's daily practices in this geographical area. Women, men and children carried the lanterns around and used them inside different buildings of homes and small businesses, around the farm, when walking along the road, and when going to the outdoor toilets at night.

The communities studied in Senegal were relatively wealthy compared to the ones in Kenya, so even the cheapest option in the Senegalese case included several lights and phone charging. The customers could choose between different levels of power capacity, with different connection fees and monthly tariffs, and they could use it at any time of the day, although for limited total time depending on the payment. Consumption was metered and prepaid in weekly amounts. The majority of the population was connected (92.5\% according to our survey) though some could not afford it. The users appreciated the services, but expressed the following complaints: the fees charged per kilowatt hour were higher than grid tariffs of the national utility; people's low income made it difficult for some to pay their bills; and the payment system did not clearly indicate when the pre-paid electricity would be used up. A feature of the socio-cultural context that influenced the situation was that large families (polygamic) with several buildings and rooms usually shared one single connection, making it difficult also to control and coordinate the use of electricity. 


\section{Opportunities and challenges for replication}

In the Indian case, the solar mini-grid systems served almost 1000 villages in Chhattisgarh state by April 2018, according to CREDA records. CREDA's arrangement for handling many units was a top-down system with standardized, streamlined socio-technical designs, implementation processes and administrative set-up at four administrative levels (district, region, zone and state). CREDA had the freedom to develop their own institutional structures. The quality of their work in each geographical area was affected, however, of the quality of the work done by each individual administrative unit. This case is one of the few existing examples of large-scale replication of small solar mini-grids implemented for providing electricity access in poor, remote communities. Replication of a similar arrangement in other states or countries, would most likely require targeted budgets and creation of government units with space to develop suited institutional frameworks for the particular socio-technical approaches they would implement. The opportunities for financing would probably vary between states and countries, and small-scale solar PV models are still likely to meet reluctance from established political economic interests in favour of large scale power generation (Newell and Phillips 2016).

However, a new Kenyan government initiative is currently implementing 840 solar charging units for lantern renting and phone charging in some hundred villages in 13 counties, in areas where the main grid is seen as unfeasible. The project builds on the Kenyan pilot project analyzed above. The government thereby (through the utility Kenya Power) continues the process of experimentation, trying and learning as these types of solutions are still in an early phase, and clearly a niche activity which typically meets many hurdles. For instance, top leaders in Kenya Power were initially not enthusiastic about the project, even though a middle manager in the organization had secured funding from a donor. Internal routines that did not fit the project also created problems and delays. However, there were also supportive institutional conditions for this new activity, such as Kenya Power's department for so-called isolated power stations, which has gained positive experiences with solar PV. These power stations are large conventional mini-grids in county capital towns, initially operated by large diesel generators, but from 2010 onwards gradually hybridized by renewable (mostly solar PV) electricity generation. This change was initially driven by the same solar champion inside Kenya Power inspired by a study visit to solar mini-grids in West-Bengal in India. The hybridization rapidly became an established, normalized element of the upgrading and new installation of isolated power stations. This gives an interesting contrast to the government's solar lantern renting project, which is radically different from the established activities of Kenya Power and therefore requires more struggle for acceptance, institutional innovation, and new ways of thinking about rural electricity provision.

The mini-grid project in Senegal also provides broadly relevant lessons on replication especially on regulatory barriers. The company had planned to scale up to a total number of 30 mini-grids and had secured private financing for this. However, the whole plan had to be cancelled because the Senegalese government gradually decided not to accept full-cost electricity tariffs, which the company was 
dependent on. Therefore they stopped giving further licences. New regulations for uniform tariffs and cross-subsidization to companies operating in remote areas were suggested by government officials, but were not likely to be finished soon. Ambiguous regulations in this case hindered upscaling of private sector-led solar mini-grids in Senegal. The same company has moved on, and is currently implementing mini-grids in other African countries where the regulatory framework looks better, but also there they face uncertainty. (See Pedersen 2016.) However, seen from the Senegalese government's perspective, everybody in Senegal should pay the same tariff, including those who get electricity through mini-grids or other off-grid solutions.

\section{Discussion on factors that influenced the village-scale solar power supply}

The presented material has demonstrated that there was considerable variety between the three systems for village-scale solar power supply in terms of their selected technical and organizational models, types of services delivered, and the ways electricity use became integrated in social practices and everyday life surrounding these systems. In this section we discuss some of the key factors that in positive and negative ways contributed to the functioning, quality of services and replicability of these systems.

In each of the three cases the operational performance significantly depended on the quality of training and follow-up support of key personnel such as local operators, committee members and managers, not only before implementation but also regularly over time. Moreover, the project implementers' willingness and ability to be flexible and change the socio-technical configuration in response to emerging practices and unforeseen events strengthened the systems' sustainability including their contextual adaptation. However, the efforts to follow-up also added to the costs.

Moreover, the systems' relatively high degree of adaptation to the geographical and social preconditions, including socio-cultural and spatial characteristics, turned out to be a key factor contributing to their suitability for the users. For example, in the Kenyan case, a supply model with flexible lighting devices (portable lanterns) not only enhanced adaptation to a dispersed settlement pattern but also to people's existing practices of being rather mobile in their everyday life.

Another shared socio-technical feature that enhanced the systems' adaption to their social contexts was their socially attuned and flexible payment requirements, which improved affordability. The different options for subscription in the Senegalese case, for instance, made it possible for people with very low income to have a few lights and charge their phone at home. In the Kenyan case, people had the opportunity to vary the usage and electricity expenditures over time, hence adapting the system to people's fluctuating incomes. However, this flexibility also reduced the revenue compared with a situation with constant use (assuming customers could pay), which illustrates a key dilemma between affordability and economic sustainability. 
All the three projects thus adapted to the local social contexts in important ways. However, our study also revealed certain shortcomings such as lack of affordability for parts of the population (in the Senegalese and Kenyan cases), limited availability and scope of supply (in the Indian and Kenyan cases), including the absence of additional electricity services that people could have benefitted from such as use of fridges, irons and blenders. In the Kenyan case, one of the reasons for this was that the increased revenue for offering such services would be unlikely to cover the extra costs including higher battery replacement costs. The Senegalese case also demonstrated this dilemma between providing abundant supply of electricity and achieving economic sustainability. Here, people could use electricity for almost any type of appliance, but since the majority could only afford a limited amount of consumption, the potential was not utilized. The limited demand in turn harmed the economic performance, and the strategy chosen by the company to overcome this problem was to select larger, wealthier villages in their next projects.

In the Indian case it was difficult to meet people's increasing expectations and demand for electricity. Once consumers started using more and larger appliances, the standardized delivery model, based on the existing national support programs and designed to enable large-scale replication, did not have sufficient flexibility to efficiently address the rising demand across different mini-grid sites. It should be noted that at the same time, the rapid increase in people's use of electricity, facilitated by very low or zero tariffs, represented a positive achievement for the Indian project. In the other two cases, effective control mechanisms (pre-paid system with automatic disconnection in Senegal and payment per service delivery, e.g. per day of lantern rental in Kenya) and limits to affordability hindered such quick progress in electricity use.

The Indian case demonstrated large-scale replication, which in this case was made possible through building up administrative structures at different levels of the governments to take care of a large number of decentralized plants. In Kenya, the government's initiative on solar lantern charging was a much newer and less institutionalized activity, which therefore met other kinds of challenges such as mismatch with governmental implementation procedures, administrative routines and lacking systems for handling of a large number of units in several remote areas. In the Senegalese case, ambiguous regulations blocked replication. The cases demonstrate that suitable policies, regulations and government institutions, including individual government officials' acceptance of radically different socio-technical configurations are key to enabling solar mini-grids and other village-scale power plants. Due to the observed mismatch between new solutions and dominating energy systems, and the consequences thereof, this study shows that the development of unconventional energy solutions needs to be understood and set up as a gradual process of institutionalization and system innovation, which typically entails trying, failing and learning. 


\section{Conclusion and policy recommendations}

This article has analyzed practical, long-term experiences with village-scale solar electricity supply in selected, rural contexts in India, Kenya and Nepal. We aimed to identify factors that influence the relevance, usefulness and affordability of the electricity services for the users as well as the functioning and replicability of the electricity supply. Based on our three case studies we find that such achievements are enhanced by adaptation of the electricity models to people's practical needs, economic constraints, livelihoods, aspirations and settlement patterns, which helps embedding the socio-technical designs in local contexts. Here below, we present factors found to contribute to such adaptation.

A term that emerges as a central principle for such context-sensitive electricity supply is flexibility, including flexible power plant capacities, devices (like portable lamps), distribution systems, subscriptions, and payment requirements. Such flexibility and social attunement inherent in the sociotechnical design of the delivery model imply adapting the services to potential users' existing practices and economic situations. Another type of flexibility observed relates to project implementers' enduring willingness and ability to change the delivery models over time. A key source for discovering needs for adjustments are the emerging practices of people who relate to operation, maintenance and use of the local electricity system. Project implementers who are willing to be present, learn and discuss can therefore increase their opportunities to improve the systems. Though it is impossible to know in advance what such modifications will eventually imply, it is possible to include scope for mutual learning and adjustments by including a substantial degree of flexibility in the initial design.

Our cases demonstrate that a variety of sustainable, technical and organizational solutions for village scale solar power supply is possible. However, these conditions do not automatically lead to delivery models that are well adapted to the local contexts. Rather, they provide opportunities to achieve sustainable systems and will depend on the project implementers' commitment to follow a context sensitive and flexible approach, and thereby the extent to which details in the systems actually suit the contexts.

There may be several hindrances to project implementers' flexibility. They need to relate to bureaucracies and regulations, which are often inflexible and mostly developed for the conventional electricity regime. Hence, significant changes in institutions and regulatory frameworks are required to make private sector led mini-grids viable. The regulatory challenges seen in Senegal have similarities with other African countries, including Kenya, where the Energy Regulatory Commission is now in the process of developing regulations for mini-grids, while maintaining the policy of uniform tariffs (World Bank Group 2016). In general, mitigation of such challenges rests with the government, and if suitable regulatory frameworks are developed, private sector actors can do very useful work and necessary innovation, which in turn can be used in government projects. 
Economic constraints constitutes another key limitation to the socio-technical flexibility, and we find that the common expectation for economic self-sustainability through revenue collection is poorly attuned to realities on the ground - and certainly if the ambition is providing universal access. Moreover, the goals for such economic sustainability of the electricity system and affordability for all potential consumers are to a large extent conflicting. This creates a dilemma for policy makers and project implementers and contributes to the ambiguities in policies as mentioned earlier. Policy makers welcome companies to invest at the same time as the conditions for tariff setting and strategies for affordability need more attention. From the project implementer's side the dilemma tends to be addressed either by providing minimalistic electricity provision (like in our Kenyan case) at the cost of excluding many potential electricity services, or selecting larger, wealthier villages (like in the Senegalese case), excluding poorer villages from access to electricity. We also find that affordability is a much larger hindrance for universal electricity access than what is generally acknowledged in discussions about offgrid solar power where the economic differences within the rural communities are rarely taken into account.

Programs for conventional electricity provision, including the large mini-grids in county capital towns in Northern and Eastern parts of Kenya, acknowledge that the connected communities cannot pay the real cost of the services. They have therefore identified additional financing sources through cross subsidies or government budgets to cover the difference. Similar provisions would be required for solar PV based, village scale electricity supply in smaller towns and villages to guarantee economic survival of these systems. A program led by the World Bank in Kenya is now attempting to design models for cross subsidies that makes it possible to involve the private sector in a way that addresses the conflicting goals mentioned above.

A final lesson from this research is that renting of portable lanterns and provision of other electricity services without gridlines may suit areas in which mini-grids or centralized grids are not feasible, and make an important difference for people. This is relevant for large geographical areas in Sub-Saharan Africa. A renting model can provide additional and more affordable lighting compared to individually owned equipment and be a stepping-stone for further use of solar PV systems. Moreover, village-scale models (mini-grids, energy centers and charging stations) that are based on delivery of electricity services rather than distribution of solar PV equipment, tend to provide electricity in ways that reach larger portions of the populations in each place than grid extension and use of standalone solar systems.

Policy makers and donors aiming at sustainable electricity for all can contribute in several ways to improve the conditions for village-scale solar power supply. Based on lessons learned in cooperation with people at the local level, innovative support mechanisms that address pervious difficulties of subsidizing electricity provision can help project implementers (government units, private sector companies or other kinds of actors) improve their delivery models over time. Such learning processes 
would support innovation relevant for people who live under difficult conditions in areas that generally receive minimal government investments in infrastructure or other social and economic improvement. And as noted, development and up-scaling of more inclusive and sustainable power supply systems also requires innovation in policies and government programs.

\section{Acknowledgements}

Sincere thanks to each and every one of our informants as well as facilitators during our fieldworks in India, Kenya and Senegal. This research was made possible through the Research Council of Norway for the project Solar xChange, RCN grant Number 217137. The work also builds on the Solar Transitions Project, RCN grant Number 190138. We are also very thankful to our project team members Henry Gichungi, Karen O’Brien, Jonas Sandgren, Siri Eriksen, Anjali Saini and Gathu Kirubi for their contributions to the research process. We further appreciate the useful comments from two anonymous reviewers.

\section{References}

Ahlborg, H. \& Sjöstedt, M. (2015). Small-Scale Hydropower in Africa: Socio-technical designs for renewable energy in Tanzanian villages. Energy Research and Social Science 5: 20-33.

Ahlborg, H., (2017). Towards a conceptualization of power in energy transitions. Environmental Innovation and Societal Transitions 25: 122-41.

Bellanca, R., Bloomfield, E. and Rai, K. (2013). Delivering Energy for Development: Models for Achiecing Energy Success for the World's Poor. Rugby, UK: Practical Action Publishing.

Berkhout, F., Verbong, G., Wieczorek, A. J., Raven, R., Lebel, L. \& Bai, X. (2010). Sustainability experiments in Asia: innovations shaping alternative development pathways? Environmental Science \& Policy 13 (4): 261-271.

Bhattacharyya S.C., \& Palit, D. (2014). Mini-grids for Rural Electrification in Developing Countries: Analysisand Case studies from south Asia. Switzerland: Springer.

Bhattacharyya S. C., \& Palit D., (2016). Mini-grid based off-grid electrification to enhance electricity access in developing countries: What policies may be required? Energy Policy 94: 166-178.

Bhattacharyya, S. C. (2010). Shaping a sustainable energy future for India: Management challenges. Energy Policy, 38 (8): 4173-4185.

Bloomberg New Energy Finance (2016). Off-Grid Solar Market Trends Report 2016. Market Analysis

Bridge, G., Bouzarovski, S., Bradshaw, M., Eyre, N., (2013). Geographies of energy transition: Space, place and the low-carbon economy. Energy Policy 53: 331-340.

Brown, H. S. \& Vergragt, P. J. (2008). Bounded socio-technical experiments as agents of systemic change: The case of a zero-energy residential building. Technological Forecasting and Social Change 75 (1): 107-130.

Camblong, H., Sarr, J., Niang, A. T., Curea, O., Alzola, J. A., Sylla, E. H. \& Santos, M. (2009). Micro-grids project, Part 1: Analysis of rural electrification with high content of renewable energy sources in Senegal. Renewable Energy, 34 (10): 2141-2150.

Carlin K, \& Agenbroad, J. Jiog, S., Henly, C. and Wanless, E. (2017). Energy within reach. Growing the minigrid market in sub-Saharan Africa. Rocky Mountain Institute.

Chaurey, A. \& Kandpal, T. C. (2010). A techno-economic comparison of rural electrification based on solar home systems and PV microgrids. Energy Policy 38 (6): 3118-3129.

Chaurey, A., Ranganathan, M. \& Mohanty, P. (2004). Electricity access for geographically disadvantaged rural communities - technology and policy insights. Energy Policy, 32 (15): 1693-1705. 
ESMAP. (2015). Beyond connections. Energy access redefined. ESMAP/Sustainable Energy 4 All (SE4ALL). Technical Report 008/15.

EUEI PDF. (2014). Mini-grid Policy Toolkit: Policy and Business Frameworks for Succssful Minigrid Roll-outs. Eschborn: European Union Energy Initiative Partership Dialiogue Facility (EUEI PDF).

Fuenfschilling, L. \& Truffer, B. (2014). The structuration of socio-technical regimes - conceptual foundations from institutional theory. Research Policy, 43 (4): 772-791.

Geels, F. W. (2011). The multi-level perspective on sustainability transitions: Responses to seven criticisms. Environmental Innovation and Societal Transitions 1 (1): 24-40.

GOGLA, Lighting Global and Berenschot. Global Solar Off-Grid Semi Annual Market Report July December 2015.

Herr, K. \& Anderson, G. L. (2005). The Action Research Dissertation: A Guide for Students and Faculty. London, United Kingdom: Sage Publications.

IEA (2014) Africa Energy Outlook: A Focus on Energy Prospects in sub-Saharan Africa. Special Report. International Energy Agency, Directorate of Global Energy Economic.

IEA. (2011). Energy for all: Financing access for the poor. Special excerpt of World Energy Outlook.

IRENA (2016), Innovation Outlook: Renewable Mini-grids, International Renewable Energy Agency, Abu Dhabi.

IRENA (2017), REthinking Energy 2017: Accelerating the global energy transformation. International Renewable Energy Agency. Abu Dhabi.

Jacobson, A. (2007). Connective Power: Solar Electrification and Social Change in Kenya. World Development, 35 (1): 144-162.

Jolly, S., Raven, R. \& Romijn, H. (2012). Upscaling of business model experiments in off-grid PV solar energy in India. Sustainability Science, 7 (2): 199-212.

Kalleberg, R. (2009). Can normative disputes be settled rationally? In Cherkaoui, M., Hamilton, P. \& Boudon, R. (eds) Raymond Boudon: a life in sociology: essays in honour of Raymond Boudon, pp. Vol. 2, pp. 251-269. Oxford, UK: The Bardwell Press.

Kirubi, C., Jacobson, A., Kammen, D. M. \& Mills, A. (2009). Community-Based Electric Micro-Grids Can Contribute to Rural Development: Evidence from Kenya. World Development 37 (7): $1208-1221$.

Leach, M., Scoones, I. \& Stirling, A. (2010). Dynamic sustainabilities: technology, environment, social justice. London: Earthscan.

Millinger, M., Mårlind, T. \& Ahlgren, E. O. (2012). Evaluation of Indian rural solar electrification: A case study in Chhattisgarh. Energy for Sustainable Development, 16 (4): 486-492.

Muchunku, C.,Ulsrud, K., Palit, D. \& Jonker-Klunne W. (2018). Diffusion of solar in East Africa: What can be learned from private sector delivery models?. WIREs Energy Environ. https://doi.org/10.1002/wene.282

Naber, R., Raven, R., Kouw, M. and Dassen, T. (2017). 'Scaling up sustainable energy innovations'. Energy Policy 110: 342-54.

Newell, P., \& Phillips, J., (2016) Neoliberal energy transitions in the South: Kenyan experiences. Geoforum 74: 39-48.

Ockwell, D. \& Byrne, R. (2017). Sustainable energy for all: Innovation, technology and pro poor green transformations. Routledge, New York.

Ockwell, D., Newell, P., Geall, S., Mbeva, K., Shen, W. and Ely, A. (2017). The Political Economy of State-led Energy Transformations: Lessons from Solar PV in Kenya and China, STEPS Working Paper 92, Brighton: STEPS Centre.

Ornetzeder, M. \& Rohracher, H. (2005). Social Learning, Innovation and Sustainable technology. In Filho, W. L. (ed.) Handbook of sustainability research, pp. 147-175. Frankfurt: Peter Lang.

Palit, D. (2013). Solar energy programs for rural electrification: Experiences and lessons from South Asia. Energy for Sustainable Development, 17 (3): 270-279.

Palit, D., Sovacool, B. K., Cooper, C., Zoppo, D., Eidsness, J., Crafton, M., Johnson, K., and Clarke, S. (2013).The trials and tribulations of the Village Energy Security Programme (VESP) in India. Energy Policy 57: 407-413. 
Patton, M. Q. (2002). Qualitative Research \& Evaluation Methods. 3 ed. London, United Kingdom: Sage Publications.

Pedersen, M., (2016). Deconstructing the concept of renewable energy-based mini-grids for rural electrification in East Africa. WIREs Energy Environ 5: 570-587.

Rohracher, H. (2003). The Role of Users in the Social Shaping of Environmental Technologies. Innovation: The European Journal of Social Science Research 16 (2): 177-192.

Rolffs, P., Ockwell, D., Byrne, R., (2015). Beyond technology and finance: pay-as-you-go sustainable energy access and theories of social change. Environment and Planning A 47: 2609-2627.

Russell, S. \& Williams, R. (2002). Social shaping of technology: Frameworks, findings and implications for policy with glossary of social shaping concepts. In Williams, R. \& Sørensen, K. H. (eds) Shaping technology, guiding policy: concepts, spaces and tools. Cheltenham: Edward Elgar.

Sareen, S. (2017). Energy distribution trajectories in two Western Indian states: compara- tive politics and sectoral dynamics, Energy Research and Social Science 35: 17-27.

Shove, E. 2003. Comfort, cleanliness and convenience: the social organization of normality. Oxford and New York: Berg Publishers.

Shrank, S. (2008). Another Look at Renewables on India's Sagar Island. Working Paper \#77, July 2008. Program on Energy and Sustainable Development (PESD), Stanford.

Smith, A. \& Stirling, A. (2010). The politics of social-ecological resilience and sustainable sociotechnical transitions, Ecology \& Society 15 (1): 11. [online] URL: http://www. ecologyandsociety.org/vol15/iss 1/art11/.

Standal, K., Winther, T. \& Danielsen, K. (forthcoming). Between kitchens, capitalism and justice: Gender in the politics of energy. In K. J. Hancock \& J. E. Allison (eds.), Oxford Handbook on the Politics of Energy (forthcoming). Chapter 12.

Ulsrud K., (2015). Village-level solar power in practice: Transfer of socio-technical innovations between India and Kenya, PhD Dissertation, Department of Sociology and Human Geography, Faculty of Social Sciences, University of Oslo.

Ulsrud, K et al., forthcoming: Mini-grids and sustainable electricity access: Practical experiences, lessons and solutions from Senegal, book manuscript.

Ulsrud, K., Winther, T., Palit, D. \& Rohracher, H. (2015). Village-level solar power in Africa: Accelerating access to electricity services through a socio-technical design in Kenya. Energy Research \& Social Science 5: 34-44.

Ulsrud, K., Winther, T., Palit, D., Rohracher, H. \& Sandgren, J. (2011). The Solar Transitions research on solar mini-grids in India: Learning from local cases of innovative socio-technical systems. Energy for Sustainable Development 15 (3): 293-303.

Wilhite, H. (2008b). New thinking on the agentive relationship between end-use technologies and energy-using practices. Energy Efficiency 1: 121-130.

Wilhite, H., (2008a). Consumption and the transformation of everyday life: A view from South India. London: Palgrave Macmillan.

Williams, R. \& Sørensen, K. H. (eds). (2002). Shaping technology, guiding policy: concepts, spaces and tools. Cheltenham: Edward Elgar.

Winther, T., (2008). The impact of electricity: Development, desires and dilemmas. Oxford, UK: Berghahn Books.

Winther, T., Ulsrud, K. \& Saini, A. (forthcoming/this volume). Solar powered electricity access: implications for women's empowerment in Rural Kenya.

Wong, S. (2012). Overcoming obstacles against effective solar lighting interventions in South Asia. Energy Policy, 40 (0): 110-120.

World Bank Group (2016). Current activities and challenges to scaling up mini-grids in Kenya. Washington DC, USA.

Yadoo, A. \& Cruickshank, H. (2012). The role for low carbon electrification technologies in poverty reduction and climate change strategies: A focus on renewable energy mini-grids with case studies in Nepal, Peru and Kenya. Energy Policy 42: 591-602. 